\title{
THE ROLE OF EXPERT WITNESSES IN COMPENSATION OF NON - PECUNIARY DAMAGE PROCEEDINGS IN THE LEGAL SISTEM OF THE REPUBLIC OF SERBIA
}

\author{
Danijela Petrović, \\ Assistant Professor, Faculty of Law, University of Priština, \\ Kosovska Mitrovica \\ danijela.petrovic@pr.ac.rs
}

\begin{abstract}
Protection of violated or endangered rights and determination of facts in court proceedings often go beyond the field of law and require the involvement of experts in other fields. In dealing with technical, medical, economic, and other issues, expert witnesses are hired whose findings and opinions can be crucial and influence the final court decision. For this reason, it is important that the expert witness has human and professional qualities that qualify him for the expert witnessing job. The existing legal solutions do not envisage training or the obligation of continuous professional development of expert witnesses, which may adversely affect the quality of expertise and the efficiency of court proceedings. In this respect, it is necessary to improve the existing legal framework and to categorize and license the expert witnesses in order for their engagement to be in accordance with court requirements. In addition to the training of expert witnesses, it is necessary to improve the training of judges. For the purposes of deciding in intangible damage compensation proceedings, judges must be aware of medical law, as lack or insufficient knowledge of medical law can be the reason for accepting expert witness findings without objection.
\end{abstract}

Keywords: court proceedings, expert witness, expert witnessing, expertise, nonpecuniary damage

\section{Criteria and conditions for performing expertise work}

Engagement of judicial expert witnesses in the legal system of the Republic of Serbia, as well as in most modern legal systems, is common practice. The fact that numerous questions in conducting procedures of protection of endangered and damaged rights can't be solved without an expert witness, indicates their importance and role in resolving disputes.

Expert witness work in the Republic of Serbia can be performed by a qualified person who fulfills terms and conditions predicted by the Law on Court Expert Witnesses (hereinafter LFEW). ${ }^{1}$ Observed in a broader sense expert witness can be

\footnotetext{
${ }^{1}$ Law on Forensic Expert Witnesses „Official gazette RS“, No. 44/ 2010.
} 
anybody who has professional knowledge in certain areas, while in a narrower sense, an expert witness is a person who submits his/her expert knowledge in the form of expertise to the court, administrative bodies, private individuals, companies and institutions. ${ }^{2}$ The expertise of expert witnesses can be announced in both written and oral form. ${ }^{3}$

Performing the work of an expert witness may be performed as a primary or secondary occupation. Ususally there is need for one expert witness for performing expertise work, but if the complexity of the dispute so requires, there can be hired two or more expert witnesses. In article 22. of the LFEW it is predicted that expertise work can perform also legal entities (expertise work is entrusted to faculties, laboratories, institutes, hospitals, etc.).

An expert witness is engaged by the court, state prosecutor's office, or a body that conducts the procedure. The role of the expert witness is to use his/her knowledge and to assist the judge in resolving the disputed issue based on the documents and evidence. The role of an expert witness is often overestimated, so an impression can be made that expert witness makes decisions about the dispute. Although the expert witness helps the judge and can significantly influence the outcome of a dispute through expertise, doesn't mean that the expert witness is the judge. An expert witness is invited to give an expert opinion on the issues because of which they are engaged and they should not judge or adjudicate, nor discuss legal matters for which they are not qualified. Since the judge decides on the basis of expertise, that is, the conclusions of the expert witness (and not themselves), the judge must be convinced that the expertise is reliable and accurate. ${ }^{4}$ In order to obtain reliable and accurate answers and conclusions from expert witnesses, it is necessary that the asked questions are specific, clear, and understandable.

The duty of an expert witness, which is also the duty of all other witnesses, is, to tell the truth. Giving a false statement implies criminal responsibility. If a false statement has caused any damage to someone, civil liability will also be determined. In the article 119. Code of Criminal Procedure of the Republic of Serbia it is foreseen that expert witness has to take an oath before expertise work. Criminal liability of medical expert witness is also foreseen in the case of unauthorized disclosure of knowledge or secrets acquired through performing expertise. ${ }^{5}$

${ }^{2}$ G. H. Shlund, „Der Arzt als Sachvestandiger und Gutacher“, y: Laufs/Uhlenbruck, Handbuch des Arztrechts, 3, Auflage, Munchen, 2002, page 1032.

${ }^{3}$ Expertise originates from french language which means assessment, expert witness testimony, record of the performed expertise, M. Vujaklija, Leksikon stranih reči i izraza, Beograd, Prosveta, 2006, page 259.

${ }^{4}$ More about this: J. Radišić, Medicinsko pravo, Nomos, Beograd, 2008, page 319.

5 Art 141. Kriminal Code „Official gazette RS“, No. 85/2005 - corr., 107/2005 - corr., 72/2009, 111/2009, 121/2012, 104/2013, 108/2014 and 94/2016. 
An expert witness is called in a court hearing on the main dispute. For unjustified absence at the scheduled hearing, fines are envisaged for both natural and legal persons who perform expertise work. ${ }^{6}$ The obligation of the expert witness is to deliver written findings and opinions to the court no later than 15 days before the court hearing. The court will submit the delivered report to the parties in the dispute not later than eight days before the court hearing. ${ }^{7}$ The Law on Civil Procedure provides a possibility for the parties to object to the opinion and findings of the expert witness, and disagreements in this regard may lead to the hiring of another expert witness and scheduling new expertise. ${ }^{8}$ Possibility for the parties to conduct admonition to the findings and opinion of the expert witness encourages the court to control the work of the expert witness by considering the objections of the parties. The law provides the possibility of scheduling new expertise, in the case when a larger number of expert witnesses who are hired are representing statements and opinions that differ from each other and cannot be reconciled. ${ }^{9}$ In the article 265. Low on Civil Procedure, the possibility for the expert witness to be relieved of his duties as an expert witness is provided, if there are justified reasons for that (illness, closeness with the parties, etc.), as well as the fact that they can be excluded or exempted which is the court's decision.

In regard to conducting expertise work, an expert witness has the right to a reward, which they may request immediately after the court hearing. If they do not demand the reward immediately after the court hearing, they lose the right to it. The reward can be paid by the parties in advance, and if the advance is not paid, the party is ordered to pay the expert witness within eight days. ${ }^{10}$

The selection of expert witness (of any profession) besides professional knowledge and necessary experience, implies that the expert witness has human qualities that qualify them for professional expertise work. The expert witness has to be objective, impartial, and also aware of their abilities. If they do not have the knowledge, or for any other reason, are not capable to objectively and reliably establish the facts which they are engaged for and thus perform the set task, it is

\footnotetext{
${ }^{6}$ Art 267. Law on Litigation procedure „Official gazette RS“ No. 72/2011, 49/2013 - des. US 74/2013 - des. US 55/2014 and 87/2018.

7 Art 269. page 2. Law on Litigation procedure provides a deadline for submission of opinions and findings, which may not be longer than 60 days. By setting deadlines, the procedure is accelerated and the efficiency of the procedures and the work of the courts is increased.

8 Art 271. Law on Litigation procedure.

9 Art 273. Law on Litigation procedure.

10 V. Petrović-Škero: Expertise in civil proceedings in: G. Šćepanović, Z. Stanković, Z. Petrović and associates, Foresnic medical expertise of non-pecuniary damage, second edited and revised edition, "Službeni glasnik RS", 2015, page 708.
} 
their duty to inform the contracting authority of the expertise. ${ }^{11}$ Impartiality and objectivity of the expert witness imply that the findings and opinion they give will be in accordance with the code and rules of the profession they represent. This implies that the expert witness must not favor either party in the dispute, nor can they condemn their actions. With their findings and opinion, the expert witness assists in reaching a verdict, which one of the parties is usually not satisfied with. Therefore, the expert witness may be exposed to the inconvenience, pressure, or aggression of the dissatisfied party. Besides pressure, in procedures of indemnity of non-pecuniary damage expert witness, if doctor, can favorize the injured, which may result in them being more emotional towards the party whose rights have been damaged or violated. Likewise, if one of the parties in court proceedings is in a position or function, the expert witness would for the benefit or earnings they expect, to adapt the opinion and findings to the interests of that party, which would lead both to a deviation from the rules and from the truth. ${ }^{12}$ All of the above indicates that being an expert witness is not easy, but also that the expert witness must have the characteristics that allow them to stay objective and impartial in addition to the stated difficulties that they face in the expertise so that the decision made on the basis of their findings would be fair.

Given the importance and role that expert witnesses have in the process of determining injuries and providing findings that are the basis for determining compensation, adequate regulation of this area is necessary. As a proposal for adequate regulation, and in order to apply the principle of efficiency, limited expertise, and licensing of expert witnesses are listed. ${ }^{13}$ Limited expertise would imply that the expertise work the expert witness may deal with a certain period of time (four up to five years), after which they would submit a new request or their expert witness status would be automatically extended. Licensing of expert witnesses and their categorization would enable efficient hiring of expert witnesses in order not to hire expert witnesses with a higher level of knowledge and special qualifications in simpler cases. Also, in complex cases (if the categorization of the expert witness is not performed), an expert witness whose knowledge and experience are not sufficient to perform the tasks for which they are engaged may be hired, therefore they cannot adequately and precisely give an opinion and findings on the case for which they have been invited to perform expertise. ${ }^{14}$

In addition to licensing and categorizing expert witnesses, it is necessary to make changes and amendments to the existing regulations (primarily the Law on Court

\footnotetext{
11 Art 5. Code of Ethics for Court Experts, on website: www.sudski-vestaci.org.rs/kodeks.php

12 J. Marić, Ethical problems of forensic expertise of non-pecuniary damage in: G. Šćepanović, Z. Stanković, Z. Petrović and associates, op. cit., pages 202-203.

13 N. Šarkić, M. Nikolić, Expertise work as evidence in: G. Šćepanović, Z. Stanković, Z. Petrović and associates, op. cit., page 18 .

14 Ibid., op. cit., page 727.
} 
Expert Witnesses) in terms of determining the obligation of continuous professional development of expert witnesses and controlling the work of court expert witnesses in practice (dismissal of court expert witnesses due to improper, conscienceless or unprofessional expertise). ${ }^{15}$

The role and importance which expert witnesses have in procedures they have been engaged indicate their impact on the efficiency of the procedure. As it is about professional and educated people, a requirement to act in accordance with the rules of the profession and enable a faster and fairer resolution of the disputed issue is something that is expected and implied.

\section{Medical expertise in criminal proceedings and proceedings of indemnity of non-pecuniary damage - similarities and differences}

The presentation of evidence by an expert witness can be performed both in a criminal case and in civil proceedings. Injury and damage to health caused by an injury in criminal law represent the effect of an illegal act. The resulting damage in the civil law sense includes the consequences of the violation. So, while for criminal law, the act of injury due to committing an illegal act is important, for civil law, the consequences are important in terms of the pain and suffering that the injured party suffers. ${ }^{16}$

Organizing expertise work is regulated by the law, while the expertise is conducted according to the rules of science and profession. ${ }^{17}$ In order to give adequate testimony and expertise in criminal proceedings, but also in litigation procedure, it is necessary that expert witness - doctor knows laws and principles according to which court proceedings and expertise proceedings in criminal and civil proceedings are conducted, in order to give an expert opinion, without disturbing the establishment of the truth. Often, due to ignorance of the law, even good connoisseurs of medical matters can make a mistake during the expertise work and influence the outcome of the court process. If there is a situation where the damaged party, injured by a sharp object in the abdomen, when there was a puncture of the abdominal tissue, suffered serious bodily injuries and the surgeon, due to the fact that the wound was healed and that the injured person has no consequences after the medical intervention, present it

15 Amendments are provided in the National Judicial Reform Strategy for the Chapter 23 (available on: $\quad$ https://www.mpravde.gov.rs/files/Nacionalna-Strategija-reforme-pravosudja-za-period-2013.2018.-godine.pdf, 24. 5. 2020 and the Action Plan for the Implementation of the National Judicial Reform Strategy for the Chapter 23, available: tps://www.mpravde.gov.rs/tekst/2963/akcioni-planzasprovodjenje-strategije.php, 24.5. 2020.

16 More about this in: D. Čukić, Specifics and differences in the approach in performing medical forensics in criminal proceedings and in proceedings of indemnit of non-pecuniary damage in: $G$. Šćepanović, Z. Stanković, Z. Petrović and associates, op. cit., page 30.

17 N. Mrvić-Petrović, J. Ćirić, M. Počuča, Medicinska veštačenja u krivičnom i parničnom postupku, Vojnosanitetski Pregled, 2015, Vol. 72, no. 8, pages 729-735. 
as a minor bodily injury, it is clear that they are helping the defendant and reduces the possibility of adequate compensation to the damaged party. ${ }^{18}$ This example indicates that a doctor-expert witness must not, due to advances in medicine and the possibility of repairing a large number of injuries that go in favor of the defendant, facilitate their position. This is especially important in the case when the injured person is in endangered health therefore new injuries can be life-threatening. Namely, if the person who experienced some form of injury is healthy, their recovery can take place in such a way that there are no consequences that would affect their life and the performance of normal life activities. However, if the person is in endangered health, new injuries could be life-threatening even have a lethal outcome. Therefore, it is necessary for the doctor-expert witness to determine the type and severity of the injury in the expertise procedure, as well as whether and how much the injury at the time of application endangered the life of the injured. The primary question is what would have happened to the injured person if they had not been given medical help, what would be the consequences and complications of the injury in that case for their health and life. ${ }^{19}$ Therefore, the essence of expertise in criminal proceedings is that the expert witness examines the injury at the time of occurrence and assesses the threat to the life of the injured.

Forensic expertise in litigation proceedings should determine the consequences of the injury. Expertise in litigation proceedings may be performed for the purpose of determining material or non-pecuniary damage. The specifics of the expertise of non-pecuniary damage refer to the fact that it is about the expertise of the pain, fear, and suffering which occurred as a result of an injury. Due to the fact that these are categories that each person subjectively experiences differently, but also due to the lack of a clear criterion on the basis of which the intensity of pain and suffering could be measured, non-pecuniary damage expertise is the most complex expertise. The role of the expert witness is to assess the cause-and-effect relationship between the injuries and the pain suffered by the injured party. To determine the consequences of injuries on the health and life of the injured, it is necessary to determine the previous health condition of the injured. Namely, at the moment of the injury, each of the injured parties is in a certain health condition, which could more or less have an influence on the consequences of the injury being more or less severe. Therefore, the expert witness should determine the condition before the injury and point out the connection between the injury and its consequences. In addition to determining the intensity of pain suffered after the injury, it is necessary (if it is certain that the pain will last in the future) to determine future suffering and mental pain, but also future damage.

\footnotetext{
18 Ibid., page 28.
}

19 The consequence of the injury arises from the injury itself, while the cause of the complication may or may not be the injury. More about this on: Z. Stanković, G. Šćepanović, Forensic significance of the relationship between injuries and diseases, G. Šćepanović, Z. Stanković, Z. Petrović and associates, op. cit., page 55 . 
Determining future pain should include the existence of future grounds for damage, but also the intensity with which it will be manifested. In the expertise procedure, the possibility of transferring one basis of non-pecuniary damage to another should be pointed out, in order for the expert witness's findings to be adequately interpreted and accepted both by the parties and the court. ${ }^{20}$

\section{Specifics of expert witness testimony in certain forms of non-pecuniary damage}

For an expert witness, testimonies in the field of medical doctors are appointed among permanent court experts, but physicians who don't have that status can be appointed if they have the necessary knowledge and experience and they meet legal criteria. ${ }^{21}$

In litigations for indemnity of non-pecuniary damage, a physician is a medical expert (expertus medicoforensis) witness who performs medical forensics. A medical expert can be a general practitioner, a specialist doctor specializing in various areas of medicine among which are forensic medicine physicians. ${ }^{22}$ Conclusion of expertise and performing forensics are elements of forensic medical expertise (expertisis medicoforensis) which is applied when it is necessary to establish or clarify medical facts that couldn't be established without medical knowledge and experience. ${ }^{23}$ Considering that performing forensics is one form of medical activity, an expert is obliged to abide by the code of ethics for physicians. ${ }^{24}$

By the Law of Contract and Torts of the Republic of Serbia, Article 200 regulates cases in which it can be ruled that the damaged party receives financial compensation for non - pecuniary damage and the goal of that compensation. As

\footnotetext{
${ }^{20}$ Severe bodily injuries result in physical pain which is the basis for compensation for non-pecuniary damage. If the pain becomes permanent, it affects the reduction of life activity, and the compensation for non-material damage from the form of compensation for physical pain grows into compensation for the reduction of life activity. More about this in: Z. Ćirić, Forensic psychiatry, Faculty of Law, University of Niš, 2013, pages 34-35.

${ }^{21}$ Expert witness registry is in the jurisdiction of the Ministry of Justice. Based on the notification about the need for expert witnesses, that presidents of first - instance courts send to the Minister of Justice, Public Call for Expert Witnesses is published.

${ }^{22}$ Medical forensics is the only area, i.e. specialty that incorporates forensics in criminal and civil proceedings into their curriculum, which shows that only medical forensic physicians are the only ones with training in medical forensics. For further reading: D. Čukić, Specifics and diferences in the approach medical expertise in criminal proceedings and non-pecuniary damage proceedings, G. Šćepanović, Z. Stanković, Z. Petrović and associates, op. cit., page 18.

${ }^{23}$ Z. Stanković, Expertise and expert witnesses in civil proceedings in: G. Šćepanović, Z. Stanković, Z. Petrović and associates, op. cit., page 18.

${ }^{24}$ The Medical Chamber of Serbia has adopted the Code of Professional Ethics of the Medical Chamber of Serbia on 28.09.2006. (“Official gazette RS”, No. 121/07).
} 
a special form of material satisfaction, fair financial compensation can be ruled in cases of 1) physical pain suffered; 2) mental anguish suffered;3) loss of amenity as a consequence of physical injury or health impairment; 4) disfigurement (aesthetic damage); 5) violation of honor, reputation, freedom or personality rights; 6) death of a close person; 7) gear suffered. The basis for ruling fair financial compensation is the intensity of fear and pain and their duration.

Analysis in this paper will point to the specifics of performing forensics in every one of them.

Physical pain forensic expertise. Rights violation as well as the damage that occurs, causing the reaction of damaged or injured parties which represents the subjective attitude towards the event by which those rights are violated and is most often manifested in feelings of discomfort, fear, grief, anger as well as concrete physical pain.

Physical pain represents a subjective reaction to the objective injury to a body. ${ }^{25}$ Law of Contract and Torts of the Republic of Serbia predicts indemnity for the damage for suffered physical pain if the pain intensity and its duration justify it. ${ }^{26}$ The question is raised of reliable determination of physical pain suffered by the damaged party considering that the characteristic of pain is a feeling of subjective nature that is distinctive of every individual. Data about the pain that the damaged party suffers can be acquired directly from the damaged party (data acquired in such manner could be unreliable), based on the analysis of the damaged party behavior (which could provide more reliable data on the pain suffered), and based on the character of analyzed injuries (which can provide an objective determination of pain). Objective symptoms such as shivering, elevated temperature, perspiration, etc. ${ }^{27}$ that can be seen by others, may facilitate pain determination. If the pain intensity is stronger it is often followed by a moan, cry, or other visible manifestations. ${ }^{28}$

Determining damage and compensation quantification for suffered physical pain implies that all pain, from the damaging event occurring up until the treatment ending, is included. All the pain that the damaged party suffered during the treatment must be taken into consideration, and if the damaged party suffered pain after the treatment has ended, it must be included in indemnity for the loss of amenity. The task of a forensic medical expert is to determine all the hardships that the damaged party

\footnotetext{
25 Z. Petrović, N. Mrvić - Petrović, Naknada nematerijalne štete, Službeni glasnik, 2012, page 98.

${ }^{26}$ Law of Contract and Torts of the Republic of Serbia, Article 200.

27 Pain determination and pain assessment are simplified by the pain division. Character of pain, its duration and intensity, as well as its consequences, conditioned the division of pain on multiple types, so we differentiate between acute and chronic pain, pulsating pain, diffused pain, somatic pain, psychogenic pain, etc. For further reading: G. Šćepanović, Suffered pain and future physical pain, G. Śćepanović, Z. Stanković, Z. Petrović and associates, op. cit., page 87. et seq.
}

28 Ibid., page 92. 
suffered due to the injury. ${ }^{29}$ Inadequately determined hardships can lead to indemnity that is not in accordance with the pain suffered, i.e. denial of the part of the indemnity to which the damaged party is entitled.

The fact that the pain is a category for which measurement unit nor measuring instrument do not exist, aggravates determination and assessment of its intensity. In an attempt to objectify pain intensity, one - dimensional and multidimensional scales are established..$^{30}$

One - dimensional scales, which include Visual - Analog Scale, Numeric Rating Scale, Verbal Scale with four and five points, strive to determine damaged party pain intensity with relative ease (by marking the pain by the damaged party). Visual Analog Scale (VAS) is a scale with numbers from 0 to 10 , where 0 indicates that there is no pain and 10 indicates the maximum amount of pain. The damaged party is expected to point to a number on the scale according to the pain that they feel. With the Numerical Rating Scale (NRS) pain is represented with numbers from 0 to 100 where 0 indicates that there is no pain and 100 indicates the maximum amount of pain. With this scale, the intensity of pain is expressed as a percentage. Verbal Pain Scale with four points offers four pain levels, 1 - no pain, 2 - mild pain, 3 strong pain, 4 - excruciating pain. Five points scale represents pain in the following levels: 1 - mild pain, 2 - uncomfortable pain, 3 - pain is present, 4 - strong pain, 5 excruciating pain. In both types of Verbal Pain Scale, the damaged party is expected to describe and mark the pain level they are experiencing. ${ }^{31}$

Multidimensional scales are questionnaires consisting of multiple question groups to which the damaged party provides answers. The questionnaire in use is The McGill - Melzack Pain Questionnaire (MPQ) that assesses the degree of disability, cognitive and affective disorders caused by pain, and their effect on daily functioning, etc. ${ }^{32}$

During pain intensity determination it is necessary to take into account fatigue of the damaged party, their mood at the moment of establishing, i.e. expressing the pain, as well as checking whether they are under the influence of any drugs, etc. For adequate pain determination, it is necessary to take into account the personality traits of the damaged party, individual pain threshold, the level of tolerance of every individual patient, etc. ${ }^{33}$

\footnotetext{
${ }^{29}$ Ibid., page 93.

${ }^{30}$ About the numerical scales and pain measurement methods, as well as problems of their implementation:

G. Šćepanović, op. cit., pages 98 - 99; Ž. Karan, Review of the practice of applying numerical scales in expertise of non-pecuniary damage; G. Šćepanović, Z. Stanković, Z. Petrović and associates, op. cit., page 87 et seq.

${ }^{31}$ G. Šćepanović, Suffered pain and future physical pain in: G. Šćepanović, Z. Stanković, Z. Petrović and associates, op. cit., page 99.

32 Ibid.

33 Ibid., page 100 .
} 
There are different views among medical forensic experts ${ }^{34}$ on the use of numerical scales for determining pain intensity that a damaged party suffers. While a certain number of medical forensics experts accepts expressing pain numerically, following the example of neighboring countries, others consider such a way of determining pain intensity unacceptable and that it is more appropriate to express pain based on intensity manifestation as high, medium or low intensity than to do so by using numerical values. By quantifying pain by numbers, the judge who gives the final ruling and who determines the amount of compensation for the pain suffered is put in an unenviable position. If the pain intensity is expressed with a 7 on a pain scale, the question then has to rise -7 of which unit of measurement, because such a unit does not exist. From all of the above as well as other reasons that make pain measurement difficult, numerical scales are used less today. ${ }^{35}$

Forensic fear evaluation. Fear can occur as an accompanying uncomfortable feeling of injuries, but it can occur when an injury is absent. If it's manifested as short-lived and intensive experience, this is primary fear. If the fear lasts longer or it has become the permanent state of uneasiness, anxiety, or apprehension, it is a secondary fear. ${ }^{36}$

For determining and evaluating fear it is important to know what kind of person is dealt with because fear is experienced differently by different vulnerable groups (children, women who are pregnant, sick people) in comparison to an average healthy person. What also has to be considered is a fact that fear is experienced more intensely in the cases of the inevitability of unfortunate events than when they happen suddenly. ${ }^{37}$

During the process of determination of indemnity for non-pecuniary damage for the fear suffered, a medical forensic expert has to consider duration and intensity of fear, fear of medical procedures that a damaged party undergoes, fear of uncertainty of the medical treatment success, as well as other circumstances that can affect fear intensity. ${ }^{38}$

When exercising the right to indemnity of non-pecuniary damage, fear duration and level of intensity are important questions. It is considered that there is no basis for indemnity if the fear was intensive but its duration was short (one to two hours). If the

\footnotetext{
${ }^{34}$ According to the opinion of the majority of expert witnesses, scales deficiency along with difficulties in their use when determining pain intensity, are such that the practice of their application should be stopped. For further reading: Ibid., page 101; Ž. Karan, op. cit., pages $168-169$.

35 Ibid.

36 Z. Đurić, Neuropsychiatric view of non-pecuniary damage in: G. Šćepanović, Z. Stanković, Z. Petrović and associates, op. cit., pages $72-75$.

${ }^{37}$ A. Jovanović, Suffered fear and future fear, G. Šćepanović, Z. Stanković, Z. Petrović and associates, op. cit., page 136.

38 G. Šćepanović, Suffered pain and future physical pain, G. Šćepanović, Z. Stanković, Z. Petrović and associates, op. cit., page 95 .
} 
fear is of medium intensity but it lasted for a day or two, or the fear is of low intensity, but it lasted longer than two days and it has not caused mental anguish suffering, there is no basis for indemnity. ${ }^{39}$

Loss of amenity forensics. The damaged party has the right to indemnity of non-pecuniary damage because of loss of amenity if difficulties in performing daily activities occur which are the cause of mental anguish suffering, and the duration and intensity of pain and suffering justify it. Loss of amenity can be temporary or permanent which will have an effect on the level of ruled compensation. ${ }^{40}$ When determining indemnity for non- pecuniary damage it is not crucial whether the injury that caused the loss of amenity is light or severe. Often, an injury that is more severe leaves no consequences that lead to the loss of amenity, or those consequences are temporary, while the injury that is classified as a light one could lead to greater amenity loss.

Loss of amenity in the case of damaging event is not a form of non - material damage, but the basis for the indemnity. The legal basis for ruling fair indemnity is the mental anguish that the damaged party suffers because of the injuries that led to the loss of amenity. The task of an expert witness is to quantify the level of decreased activity in terms of limitations, disablement, or difficulties in performing regular activities and provide information to the court based on which the judge decides about indemnity. For the purpose of performing the given task, it is necessary that a medical expert witness examines the damaged party and establish whether the injury has occurred, what was their medical condition before the injury, and whether that concrete injury or general medical condition has led to the loss of amenity. ${ }^{41}$

Evaluation and determination of loss of amenity are based on an evaluation scale where $1-24 \%$ decrease is defined as light loss of amenity, 25 - $49 \%$ is mediumheavy, $50-74 \%$ is heavy, $75-94 \%$ is very heavy and $95-100 \%$ is defined as complete loss of ability to perform any life activity. ${ }^{42}$

For the purpose of simpler and more efficient determination of loss of amenity, the World Health Organization established the International Classification of

\footnotetext{
39 This point of view is accepted in legislations of former republics of Yugoslavia. For further reading: D. Čukić, op. cit., page 38.

${ }^{40}$ V. Govedarica, G. Šćepanović, A. Jovanović, Mental anguish due to loss of amenity, G. Šćepanović, Z. Stanković, Z. Petrović and associates, op. cit., page 117.

41 The examination is necessary to determine whether the injury occurred at all, because in order to benefit, the injured or damaged are able to simulate pain and show them greater than they really are. The role of the expert is to recognize the simulation (pretense), dissimulation (concealment) or aggravation (exaggeration), in order to determine as realistically as possible the degree of injuries and pain suffered. More about this: G. Šćepanović, Expertise of extremities injuries consequences in: G. Šćepanović, Z. Stanković, Z. Petrović and associates, op. cit., page 527.
}

${ }^{42}$ V. Govedarica, G. Šćepanović, A. Jovanović, op. cit., page 124. 
Functioning, Disability, and Health (ICF).$^{43}$ This classification that consists of two parts, encompasses functioning and disability (in the first part) and contextual factors (in the second part). ${ }^{44}$ Significant contribution in evaluating loss of amenity is one hundred degrees Social and Occupational Functioning Assessment Scale (SOFAS) which is published by the American Psychiatric Association published within the Fourth Revision of Diagnostic and Statistical Manual and Mental Disorders (DSM IV). ${ }^{45}$ European Confederation of Specialized in the Assessment and Compensation of Physical Injuries (Confederation Europeenne d' Experts en Réparation et Évaluation du Dommage Coprorel - CEREDOC) established European Indicative Scale for the assessment of physical and psychiatric damage (EIT). ${ }^{46}$ In addition to the all listed scales, Sheehan Disability Scale (SDS) for assessment of disability in professional, family, and social life caused by consequences of injuries and illnesses, Global Assessment of Functioning Scale (GAF) that shows an overall grade of individuals' functioning, as well as other scales, are in use as well. ${ }^{47}$

Expertise work of mental anguish suffered due to the severe disability of a close person. An insufficiently precise definition of severe disability complicates the work of expert witnesses and courts. Severe disability most often implies multiplied organ damage or body parts which are not necessarily followed by nervous system damage, damage of other senses, etc. ${ }^{48}$ Severe disability of a person implies that they are unable to perform basic life functions, that the personal appearance of a person is impaired which causes the feeling of grief, pain, and pity to the family, but that can also cause discomfort in other people, avoiding encounters and contacts with a severely disabled person, etc. Within a family, there are different reactions to the disability of its members. While some families are ready to accept the disability of their members, help them and strive to have a normal life (to the degree that is possible), disability in other families leads to tension and problems that cause an

43 International Classification of Functioning, Disability and Health, World Health Organization, Geneva, 2011.

44 Contextual factors are factors that come from the environment, apropos the environment (external) and personal (internal) factors that affect the functioning and disability in: G. Šćepanović, Z. Stanković, Z. Petrović and associates, op. cit., page 121.

45 American Psychiatric Association. Diagnostic and Statistical Manual of Mental Disorders, ed. 4. American Psychiatric Association, Washington DC, 1994.

46 The application of European tables does not imply the determination of compensation on the basis of a simple insight into the table, but only provides a basis for experts when determining the amount of compensation. It is not intended for the laity and it is not possible to determine the level of damage to the health of the injured party on the basis of insight into the value given in the table. More about this in: Ž. Karan, European tables for assessing impairment of physical and mental integrity, G. Šćepanović, Z. Stanković, Z. Petrović and associates, op. cit., page 177.

47 V. Govedarica, G. Šćepanović, A. Jovanović, op cit., page 127.

48 Ibid., page 145. 
increase in mental anguish of disabled person. ${ }^{49}$

Expertise work of mental anguish suffered due to disfigurement. As well as the other forms of non - material damage, there is no established objective criteria for determining disfigurement degree. Disfigurement in itself does not entitle to indemnity for non - material damage. Entitlement to indemnity is based on mental anguish that the damaged party suffers because of disfigurement. If the damaged party is not aware of the significance of the disfigurement, there is no mental anguish suffered due to the disfigurement, i.e. there is no basis for ruling indemnity. ${ }^{50}$

The role of an expert witness in the assessment of disfigurement is to determine the condition before the disfigurement occurred and the condition that occurred after the injuries. Due to the treatment options for the vast majority of the injuries and aesthetic corrections, forensics is performed after the treatment has finished. It is a separate question of whether the damaged party has the right to compensation for aesthetic procedures and interventions. The position of jurists is that the damaged party should be entitled to the compensation for aesthetic interventions if that is justified and for the purpose of injury repairment, as treatment costs (material damage), but they should also be entitled to indemnity for non - material damage because of the pain suffered. ${ }^{51}$ When determining indemnity for non - material damage, an expert witness has to take into account age of the damaged party, occupation or profession, the degree to which the injuries are visible, i.e. whether they are on body parts that are exposed and visible, or they can be hidden from other people. ${ }^{52}$ Also, the environment in which the damaged party lives should not be ignored because the intensity of mental anguish suffering can significantly be affected by the readiness of the environment to accept the damaged party, i.e. the fact that they can be rejected because of their disfigurement. If because of the disfigurement, the damaged party is prevented from performing activities which they would otherwise perform, and they refer to daily activities and activities that are in relation to the profession of the damaged party, next to the indemnity for impairment, they could claim indemnity on

49 G. Šćepanović, Z. Đurić, Mental anguish due to severe disability of a close person in: G. Šćepanović, Z. Stanković, Z. Petrović and associates, op. cit., page 144. In addition to disability, relationships in the family are also affected by chronic pain of the injured. More about this in: G. Šćepanović, Z. Stanković, Z. Petrović and associates, op. cit., page 102.

${ }^{50} \mathrm{D}$. Medić, Importance of the expertise in civil proceedings for indemnity of non-pecuniary damage,

G. Šćepanović, Z. Stanković, Z. Petrović and associates, op cit., page 695.

51 Ibid., page 696.

52 Clinical examination of the way other people see people who have experienced some form of impairment uses the distance method, which observes at a distance of $50 \mathrm{~cm}$, which involves observation by people in the immediate vicinity and from a distance of $3 \mathrm{~m}$, which is "social distance ". More about this in: V. Š. Rakić: Model of forensic classification of disfigurated disorders caused by operations, injuries, diseases and treatment, doctoral dissertation, Faculty of Medicine, University of Belgrade, 2016, page 22. 
the basis of loss of amenity. ${ }^{53}$

The expertise of mental anguish suffered due to a violation of honor, reputation, dignity, and freedom. In order to unify concepts that relate to violations of personality rights, the concept of personality integrity is used in literature. By the constitution of the Republic of Serbia, Article 18, the right to inviolability of human dignity and the right to private life are guaranteed. Violations of reputation, honor, and dignity are lately occurring through the media which causes an increase in the number of lawsuits for indemnity of non - material damage for such violations. ${ }^{54}$ The basis for indemnity of non - material damage, as well as the right to their ruling, are mental anguish suffered, i.e. psychological suffering that the damaged party experiences due to violation of reputation, honor, and dignity. ${ }^{55}$ Suffering that the damaged party whose rights are endangered or violated experiences, as well as the personality structure of the damaged party, are subjected to the expertise procedure for the violation of personality rights. Namely, expertise determines whether the damaged party caused the violation of their rights with their own behavior, which personality group they belong to, whether they have a hypersensitive or emotionally stable personality, etc. ${ }^{56}$ Expertise in the cases of violation of personality rights is complex and delicate, so it is insisted on reconciliation, apology, or mediation whenever possible, and only in those situations where reconciliation is not possible procedure for indemnity is set in motion.

\section{Conclusion}

There are numerous causes of injuries that enable exercising rights for indemnity for non - material damage. Injuries that occur as a consequence of damaging events are also numerous. The complexity of the tasks that are given to the expert witness and the significance of their opinions and conclusions to the final ruling on indemnity requires a high level of knowledge, experience, and dedication. Next to knowledge and experience, an expert witness must be distinguished by traits that enable that despite difficulties that are encountered in expertise, they stay objective and unbiased so that decision that is being made based on their findings would be fair.

Considering that there are no simple and objective criteria that would be used to "measure" non - pecuniary damage, that is, physical and mental anguish that the damaged party suffered because of the violation of personality rights, the amount of indemnity of non-pecuniary damage, as well as the estimation of monetary compensation that is ruled in the name of indemnity, it is often difficult to determine. That is why the role of an expert witness in non-pecuniary damage proceedings is especially important.

53 G. Šćepanović, Z. Đurić, op. cit., page 114.

54 M. D. Čabarkapa, Mental anguish due to violation of integrity, freedom and personality rights due to death of a close person in: G. Šćepanović, Z. Stanković, Z. Petrović and associates, op. cit., page 157.

55 Ibid., page 152-160.

56 Ibid., page 158 . 
In order to provide the most complete and high - quality expertise in civil proceedings, commissions consisting of a medical forensic expert, a psychiatrist and a doctor with specific specialty depending on the nature of the injuries, are often formed. The presence of a psychiatrist is necessary in order to adequately assess the intensity of the experienced fear, pain, and other forms of non-pecuniary damage. Because of the significance of expert witnesses in all judicial proceedings, and especially in non-pecuniary damage proceedings, improvement of the existing legal framework of this area is necessary. Adequate legislation can lead to increased efficiency of expert witness work, individuals whose rights are violated or endangered would be provided with adequate compensation, and conditions for an increase in efficiency in the Serbian judiciary would be created.

\section{Literature}

1. Akcioni plan za sprovođenje Nacionalne strategije reforme pravosuđa za Poglavlje 23, dostupno na http://www.mpravde.gov.rs/tekst/2963/akcioni-planzasprovodjenje-strategije.php;

2. American Psychiatric Association. Diagnostic and Statistical Manual of Mental Disorders, ed. 4. American Psychiatric Association, Washington DC, 1994;

3. Ćirić Z., Sudska psihijatrija, Pravni fakultet Univerziteta u Nišu, 2013;

4. Etički kodeks sudskih veštaka, dostupno na: www.sudski-vestaci.org.rs/kodeks. php

5. International Classification of Functioning, Disability and Health, World Health Organization, Geneva, 2011;

6. Jelčić O., "Novčana naknada nematerijalne štete u slučaju telesne povrede", Naša zakonitost, br. 10/82, Zagreb, 1982;

7. Krivični zakonik "Službeni glasnik $R S$ " br. 85/2005 - ispr., 107/2005 - ispr., 72/2009, 111/2009, 121/2012, 104/2013, 108/2014 i 94/2016;

8. Laufs/Uhlenbruck, Handbuch des Arztrechts, 3, Auflage, Munchen, 2002;

9. Law on Forensic Expert Witnesses „Official gazette RS“, No. 44/ 2010;

10. Nacionalna strategija reforme pravosuđa za Poglavlje 23, dostupna na: https:// www.mpravde.gov.rs/files/Nacionalna-Strategija-reforme-pravosudja-zaperiod-2013.-2018. godine.pdf;

11. Nataša Mrvić-Petrović, Jovan Ćirić, Milan Počuča, „Medicinska veštačenja u krivičnom i parničnom postupku", Vojnosanitetski Pregled, 2015, Vol. 72, no. 8;

12. Radišić J., Medicinsko pravo, Nomos, Beograd, 2008;

13. Petrović Z., Mrvić-Petrović N., Naknada nematerijalne štete, Službeni glasnik, 2012;

14. Rakić Š. V., Model sudsko - medicinske klasifikacije naruženja nastalih kao posledica operacija, povreda, oboljenja i lečenja, doktorska disertacija, Univerzitet u Beogradu, Medicinski fakultet 2016; 
15. Šćepanović G., Stanković Z., Petrović Z., i saradnici, Sudsko-medicinsko veštačenje nematerijalne štete, drugo izmenjeno i dopunjeno izdanje, Službeni glasnik, 2015;

16. Vujaklija M., Leksikon stranih reči i izraza, Beograd, Prosveta, 2006. 